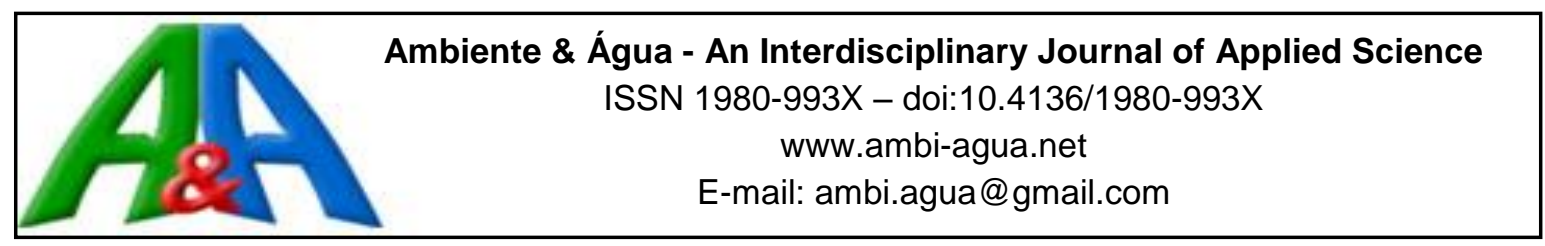

\title{
The historical influence of tributaries on the water and sediment of Jacuí's Delta, Southern Brazil
}

\author{
ARTICLES doi:10.4136/ambi-agua.2150
}

Received: 15 Jun. 2017; Accepted: 07 Jan. 2018

\section{Leonardo Capeleto de Andrade ${ }^{1 *}$; Rodrigo da Rocha Andrade²; Flávio Anastácio de Oliveira Camargo ${ }^{1}$}

\author{
${ }^{1}$ Universidade Federal do Rio Grande do Sul (UFRGS), Porto Alegre, RS, Brasil \\ Departamento de Solos. E-mail: eng.capeleto@gmail.com, fcamargo@ufrgs.br \\ ${ }^{2}$ Departamento Municipal de Água e Esgotos (DMAE), Porto Alegre, RS, Brasil \\ E-mail: rodrigora@dmae.prefpoa.com.br \\ *Corresponding author
}

\begin{abstract}
The high population density in a metropolis leads to socio-environmental impacts that directly affect local water resources. This work evaluated the historical data (between 2000 and 2014) of water and sediment monitoring in the Jacuí's Delta region and analyzed the relationship between these sites. Seven monitoring sites around the Jacuís Delta were evaluated: the outflow of the rivers Jacuí, Caí, Sinos, and Gravataí; the channels Ilha da Pintada and Navegantes; and Lake Guaíba. Water data were evaluated for: air and water temperature; depth; $\mathrm{pH}$; electrical conductivity; transparency; turbidity; dissolved oxygen; biochemical oxygen demand; phosphorus; nitrogen; total residues; and escherichia coli. Sediment were evaluated for pseudo-total concentrations of metals (Al, Fe, $\mathrm{Ca}, \mathrm{Mn}, \mathrm{Ba}, \mathrm{V}, \mathrm{Zn}, \mathrm{Cu}, \mathrm{Pb}, \mathrm{Cr}, \mathrm{Ni}$, $\mathrm{Co}, \mathrm{Li}, \mathrm{Be}, \mathrm{Cd}, \mathrm{Hg}, \mathrm{As}$, and $\mathrm{Ag}$ ). The quality of water and sediment in the Jacuí's Delta are linked with the tributaries and priority flows of the channels. The historical data of water and sediment around the Jacuí's Delta shows the influence of the tributaries with low quality in the downstream points. The pollution of the rivers Caí, Sinos, and Gravataí negatively affects the environmental quality of the channel Navegantes and Lake Guaíba (catchment points to water supply). The water in those sites presents reductions in dissolved oxygen and high values of coliforms, and the sediment shows high concentrations of metal $\mathrm{Zn}, \mathrm{Pb}, \mathrm{Cr}$, and $\mathrm{Hg}$. Despite the reduction in $\mathrm{Pb}$ and $\mathrm{Hg}$ values in the sediment over the past years, pollution from the tributary rivers still persists.
\end{abstract}

Keywords: monitoring, pollution, watershed.

\section{A influência histórica dos afluentes na água e sedimento do Delta do Jacuí, RS, Brasil}

\section{RESUMO}

A grande densidade populacional nas metrópoles gera impactos socioambientais que afetam diretamente os recursos hídricos locais. O objetivo deste trabalho foi avaliar os dados históricos (entre 2000 e 2014) de monitoramento de água e sedimentos na região Delta de Jacuí e analisar a relação entre esses locais. Foram avaliados sete locais de monitoramento entorno do Delta de Jacuí: foz dos rios Jacuí, Caí, Sinos e Gravataí; canais Ilha da Pintada e Navegantes; e Lago Guaíba. Os dados de água foram avaliados para: temperatura do ar e da água; 
profundidade; $\mathrm{pH}$; condutividade elétrica; transparência; turbidez; oxigênio dissolvido; demanda bioquímica de oxigênio; fósforo; nitrogênio; resíduos totais; e escherichia coli. Os sedimentos foram avaliados para concentrações pseudo-totais de metais ( $\mathrm{Al}, \mathrm{Fe}, \mathrm{Ca}, \mathrm{Mn}, \mathrm{Ba}$, $\mathrm{V}, \mathrm{Zn}, \mathrm{Cu}, \mathrm{Pb}, \mathrm{Cr}, \mathrm{Ni}, \mathrm{Co}, \mathrm{Li}, \mathrm{Be}, \mathrm{Cd}, \mathrm{Hg}, \mathrm{As}$ e Ag). A qualidade da água e dos sedimentos no delta de Jacuí está ligada aos afluentes e fluxos prioritários dos canais. Os dados históricos de água e sedimentos no Delta de Jacuí mostram a influência dos afluentes com baixa qualidade nos pontos a jusante. A poluição dos rios Caí, Sinos e Gravataí afeta negativamente a qualidade ambiental do canal Navegantes e do Lago Guaíba (pontos de captação para abastecimento hídrico). A água nesses locais apresenta reduções no oxigênio dissolvido e grandes valores de coliformes e o sedimento apresenta grandes concentrações dos metais $\mathrm{Zn}, \mathrm{Pb}, \mathrm{Cr}$ e $\mathrm{Hg}$. Apesar da redução ao longo dos anos nos valores de $\mathrm{Pb}$ e $\mathrm{Hg}$ no sedimento, a poluição dos rios tributários ainda persiste.

Palavras-chave: bacia hidrográfica, monitoramento, poluição.

\section{INTRODUCTION}

The large expansion of big cities results in environmental impacts on local water resources, which often serve as a source of water for the same populations (Cavalcanti et al., 2014). Trace metals entering aquatic ecosystems through runoff or atmospheric deposition and eventually accumulate in sediments (Bing et al., 2016).

Lake Guaíba is the major source of water in the capital of the Rio Grande do Sul State. The lake has had historical, economic and cultural importance for the region since the 18th century. With almost $500 \mathrm{~km}^{2}$ of shallow waters, Lake Guaíba is the final destination of the rivers Jacuí, Caí, dos Sinos, and Gravataí - accumulating potential liabilities generated in the drainage basin. Water pollution in Lake Guaíba's watershed has been noted since the end of 1950 (Freitas, 1962; Roessler, 2005), persisting for decades as a public perception. Nowadays, the waters have multiples uses: as water supply, sewage dilution, navigation, as well as fishing (Andrade et al., 2018).

The Jacuí's Delta (Figure 1) is an area of protection and great socio environmental interest, being the archipelago of a State Conservation Unit. This work evaluated the historical data (between 2000 and 2014) of water and sediments monitoring, developed by the Municipal Department of Water and Sewage (Dmae) of Porto Alegre in the Jacuí's Delta region. This work also analyzed the relationship between the sites. 


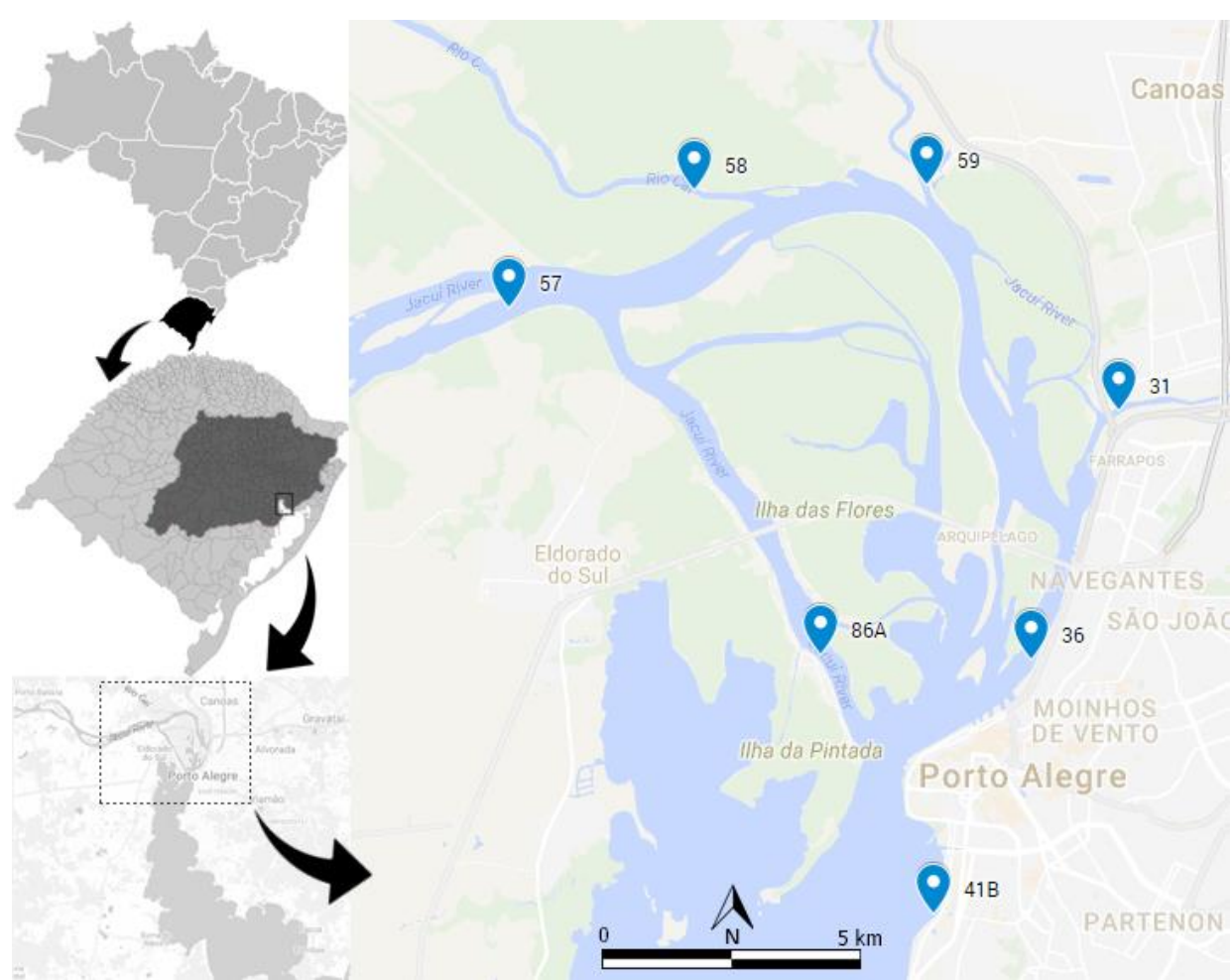

Figure 1. Sampling sites (31 - Gravataí River; 36 - Navegantes Channel; 41B Lake Guaíba; 57 - Jacuí River; 58 - Caí River; 59 - dos Sinos River; 86A - Ilha da Pintada Channel) of water and sediment in Jacuí's Delta. The darker area in the state map represents the lake's drainage basin.

Source: Google Maps.

\section{MATERIALS AND METHODS}

Analyses of water and sediment monitoring were carried out by the Municipal Department of Water and Sewage (Dmae) of Porto Alegre, RS, between 2000 and 2014. The seven sites evaluated around the Jacuí's Delta (Figure 1) were: 31 - Gravataí River outflow

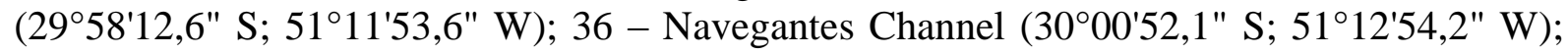
41B - Lake Guaíba $\left(30^{\circ} 03^{\prime} 32,7^{\prime \prime}\right.$ S; 51 $144^{\prime} 10,3^{\prime \prime}$ W); 57 - Jacuí River outflow

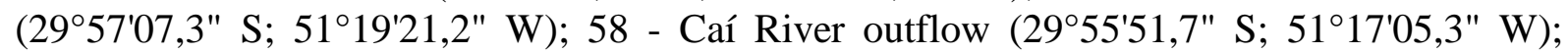

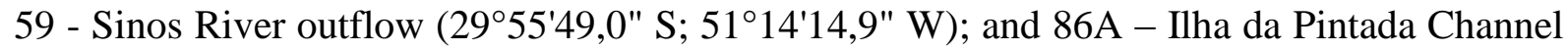
$\left(30^{\circ} 00^{\prime} 49,0^{\prime \prime} \mathrm{S} ; 51^{\circ} 15^{\prime} 34,2^{\prime \prime} \mathrm{W}\right)$. Some of these sites are points of water catchment for Water Treatment Plants (WTP): 36 - São João and Moinhos de Ventos; 41B - Menino Deus; and 86A - Ilha da Pintada. Site numbers are standards codes defined by Dmae.

Water data, with monthly repetitions between the years 2000 and 2014, were evaluated for: air and water temperature; depth; $\mathrm{pH}$; electrical conductivity (EC); transparency (secchi disk); turbidity (NTU); dissolved oxygen (DO - modified Winkler); biochemical oxygen demand $\left(\mathrm{BOD}_{5}\right.$ - manometric); total phosphorus $(\mathrm{P}$ - titulometric); total nitrogen $(\mathrm{N}$ titulometric); total residues at $105^{\circ} \mathrm{C}$ ( $\mathrm{TR}_{105}$ - gravimetric); and escherichia coli (enzymatic substrate). Sediment (bulk) was oven-dried $\left(50^{\circ} \mathrm{C}\right)$ and evaluated, with two annual repetitions in distinct seasons between the years of 2000 and 2011, to pseudo-total (USEPA, 2007) concentrations (dry basis) of metals (Al, Fe, Ca, Mn, Ba, V, Zn, Cu, Pb, Cr, Ni, Co, $\mathrm{Li}, \mathrm{Be}, \mathrm{Cd}$, $\mathrm{Hg}$, As, and $\mathrm{Ag}$ ) and analyzed by atomic absorption spectrophotometry.

Data were submitted to analysis of variance (ANOVA) and, when significant, means were compared by Tukey test with a $95 \%$ confidence interval $(p<0.05)$. All graphs and statistical analyzes were developed in Statistica ${ }^{\circledR}$ v13 software. 


\section{RESULTS AND DISCUSSION}

The quality of water and sediment in the Jacuí's Delta are linked with the tributaries and priority flows of the channels (Figure 1). Lake Guaíba has a historical mean water inflow of $780 \mathrm{~m}^{3} \mathrm{~s}^{-1}$ (with occasional events exceeding $3000 \mathrm{~m}^{3} \mathrm{~s}^{-1}$ ). This inflow is composed mostly $(85 \%)$ of waters from Jacuí River (point 57 ) and the remaining by the Rivers Sinos, Caí, and Gravataí (flowing into the Jacuí's Delta), as well as small streams along the margins (Menegat et al., 2006; Andrade Neto et al., 2012; Porto Alegre, 2017b).

The relationship of the forming rivers with the Jacuí's Delta is observed in the cluster analysis (Figure 2a), such at Points 57 (Jacuí River outflow) and 86A (the channel of the Jacuí Delta - Ilha da Pintada). However, the greatest influence of the tributaries is verified by the accumulation of liabilities of the Rivers Caí (58), Sinos (59), and Gravataí (31) over the channel Navegantes (36) and Lake Guaíba (41B). The Rivers Caí and Sinos flow through regions with many industries, especially leather and footwear; and Gravataí River flows through the metropolitan region of Porto Alegre.

The pollution from tributaries can be verified by the increase in electrical conductivity (EC), biochemical oxygen demand (BOD5), P, N, TR105, and coliforms in water (Table 1), and metals (such as $\mathrm{Zn}, \mathrm{Cu}, \mathrm{Pb}, \mathrm{Cr}, \mathrm{Ni}$, and $\mathrm{Hg}$ ) in the surface sediment (Table 2) in the downstream points (such as 36 and 41B). Consequences of these changes are reductions in $\mathrm{pH}$, dissolved oxygen (DO), and water transparency - which can result in damage to local biota.

These parameters have direct and indirect connections with the urban pollution commonly present in metropolitan regions (Figure 2b). Metals and other pollutants enter the aquatic environment by various ways and sources (natural and anthropogenic), such as runoff, sewage, atmospheric deposition, and vehicular traffic (Smol, 2008; Bing et al., 2016). High vehicular traffic has been reported around the world as a potential source of pollution by metals (Zhang et al., 2016; Sharley et al., 2016). Motor vehicles have a variety of emissions and releases involving many toxic metals (such as $\mathrm{Zn}, \mathrm{Cr}, \mathrm{Cu}, \mathrm{Hg}, \mathrm{Ni}$, and $\mathrm{Pb}$ ), which damage human health and the environment (Adamiec et al., 2016). 

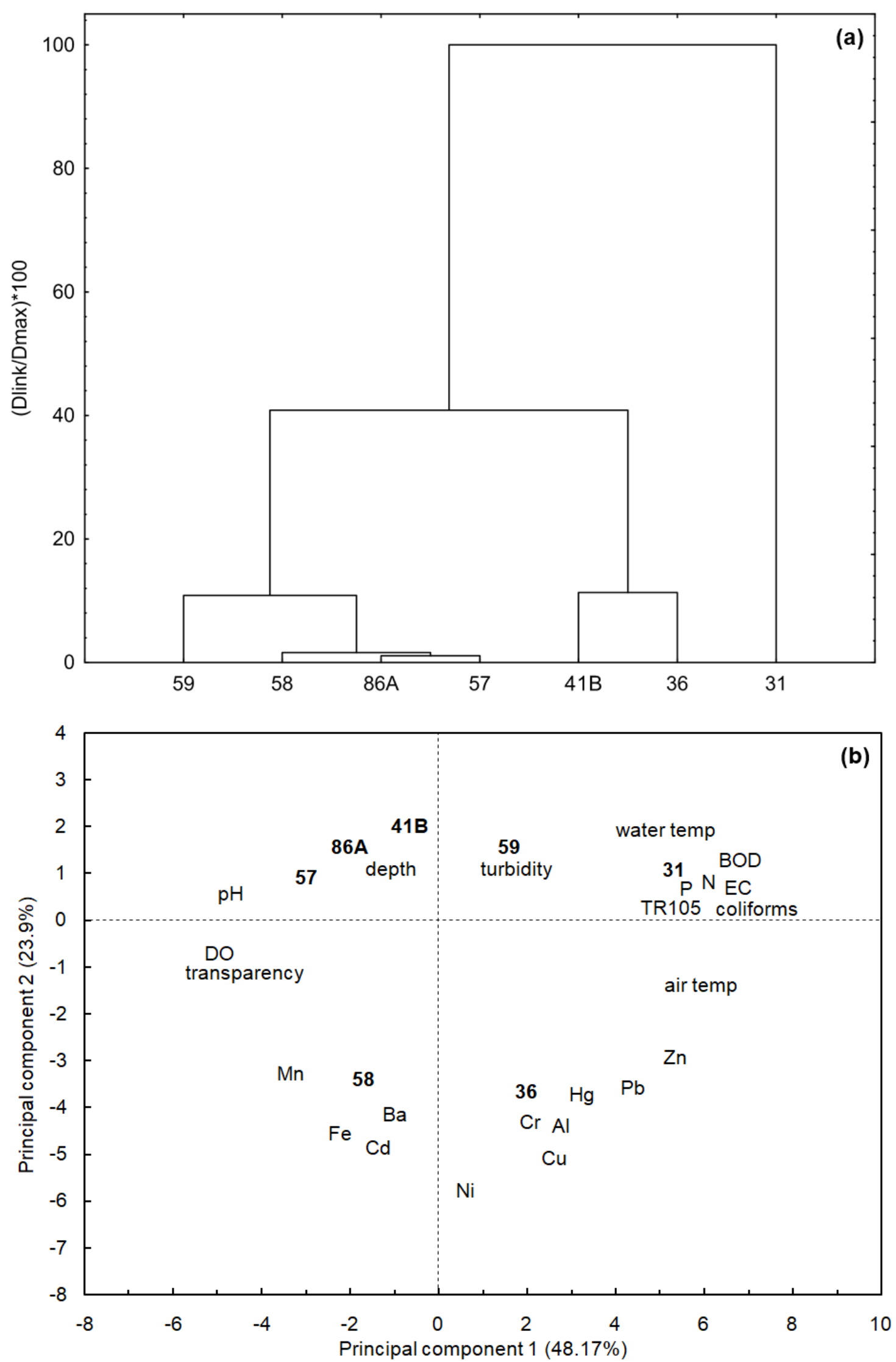

Figure 2. Analysis of (a) clusters for the sites and (b) principal components for water and sediment in Jacuí's Delta. 
Table 1. Historical means (2000 to 2014) of water parameters around the Jacuí's Delta.

\begin{tabular}{|c|c|c|c|c|c|c|c|}
\hline Parameters & $\begin{array}{c}31 \\
\text { Gravataí River }\end{array}$ & $\begin{array}{c}\mathbf{3 6} \\
\text { Navegantes }\end{array}$ & $\begin{array}{c}\text { 41B } \\
\text { Lake Guaíba }\end{array}$ & $\begin{array}{c}\mathbf{5 7} \\
\text { Jacuí River }\end{array}$ & $\begin{array}{c}\mathbf{5 8} \\
\text { Caí River } \\
\end{array}$ & $\begin{array}{c}59 \\
\text { Sinos River }\end{array}$ & $\begin{array}{c}\text { 86A } \\
\text { Ilha da Pintada }\end{array}$ \\
\hline air temperature $\left({ }^{\circ} \mathrm{C}\right)$ & $22.0 \pm 0.4^{\mathrm{a}}$ & $21.8 \pm 0.4^{\mathrm{a}}$ & $21.0 \pm 0.4^{\mathrm{a}}$ & $21.0 \pm 0.4^{\mathrm{a}}$ & $21.2 \pm 0.4^{\mathrm{a}}$ & $21.5 \pm 0.4^{a}$ & $21.5 \pm 0.4^{\mathrm{a}}$ \\
\hline water temperature $\left({ }^{\circ} \mathrm{C}\right)$ & $21.6 \pm 0.4^{\mathrm{a}}$ & $21.2 \pm 0.4^{\text {a }}$ & $21.2 \pm 0.4^{\mathrm{a}}$ & $21.1 \pm 0.4^{\mathrm{a}}$ & $20.8 \pm 0.4^{\mathrm{a}}$ & $20.9 \pm 0.4^{\text {a }}$ & $21.1 \pm 0.4^{\mathrm{a}}$ \\
\hline depth $(m)$ & $4.5 \pm 0.1^{\text {ed }}$ & $6.6 \pm 0.0^{c}$ & $9.6 \pm 0.1^{a}$ & $8.7 \pm 0.0^{b}$ & $4.4 \pm 0.1^{\mathrm{e}}$ & $4.6 \pm 0.0^{\mathrm{d}}$ & $4.0 \pm 0.0^{\mathrm{f}}$ \\
\hline pH & $6.9 \pm 0.0^{\mathrm{d}}$ & $7.0 \pm 0.0^{\mathrm{bc}}$ & $7.0 \pm 0.0^{b}$ & $7.2 \pm 0.0^{\mathrm{a}}$ & $7.0 \pm 0.0^{\mathrm{b}}$ & $6.9 \pm 0.0^{\mathrm{cd}}$ & $7.2 \pm 0.0^{\mathrm{a}}$ \\
\hline $\mathbf{E C}\left(\mu \mathrm{S} \mathrm{cm}^{-1}\right)$ & $185.6 \pm 7.7^{a}$ & $88.1 \pm 1.4^{\mathrm{cd}}$ & $80.8 \pm 1.1^{\mathrm{d}}$ & $54.0 \pm 0.6^{\mathrm{e}}$ & $97.6 \pm 2.7^{\mathrm{c}}$ & $132.8 \pm 3.9^{b}$ & $54.4 \pm 0.7^{\mathrm{e}}$ \\
\hline Transparency (cm) & $26.1 \pm 0.7^{\mathrm{d}}$ & $43.1 \pm 1.2^{b c}$ & $44.6 \pm 1.3^{a b c}$ & $54.2 \pm 2.3^{\text {a }}$ & $48.4 \pm 1.9^{a b c}$ & $39.2 \pm 1.1^{\mathrm{c}}$ & $51.3 \pm 2.7^{a b}$ \\
\hline Turbidity (NTU) & $38.9 \pm 1.6^{\mathrm{a}}$ & $31.1 \pm 1.1^{\text {a }}$ & $32.5 \pm 1.4^{\text {a }}$ & $36.4 \pm 2.6^{a}$ & $36.6 \pm 2.5^{\mathrm{a}}$ & $33.2 \pm 1.5^{\mathrm{a}}$ & $36.7 \pm 2.3^{\mathrm{a}}$ \\
\hline $\mathbf{D O}\left(\mathrm{mg} \mathrm{O}_{2} \mathrm{~L}^{-1}\right)$ & $2.65 \pm 0.16^{\mathrm{e}}$ & $5.92 \pm 0.09^{\mathrm{c}}$ & $6.06 \pm 0.07 \mathrm{bc}$ & $7.93 \pm 0.08^{a}$ & $6.54 \pm 0.09^{b}$ & $3.86 \pm 0.12^{d}$ & $7.76 \pm 0.08^{a}$ \\
\hline $\mathbf{B O D}_{\mathbf{5}}\left(\mathrm{mg} \mathrm{O}_{2} \mathrm{~L}^{-1}\right)$ & $8.22 \pm 0.48^{a}$ & $1.95 \pm 0.06^{b c}$ & $1.77 \pm 0.06^{\mathrm{bcd}}$ & $0.77 \pm 0.04^{\mathrm{e}}$ & $1.22 \pm 0.06^{\mathrm{cde}}$ & $2.64 \pm 0.11^{b}$ & $0.87 \pm 0.05 \mathrm{de}$ \\
\hline Phosphorus (mg L $\left.{ }^{-1}\right)$ & $0.54 \pm 0.03^{a}$ & $0.19 \pm 0.01^{b c}$ & $0.16 \pm 0.00^{\mathrm{cd}}$ & $0.08 \pm 0.00^{\mathrm{e}}$ & $0.12 \pm 0.01$ de & $0.21 \pm 0.00^{b}$ & $0.08 \pm 0.00^{\mathrm{e}}$ \\
\hline Nitrogen $\left(\mathrm{mg} \mathrm{L}^{-1}\right)$ & $5.96 \pm 0.27^{\mathrm{a}}$ & $2.17 \pm 0.07^{\mathrm{c}}$ & $2.00 \pm 0.06^{\mathrm{c}}$ & $1.29 \pm 0.03^{\mathrm{d}}$ & $1.97 \pm 0.05^{\mathrm{c}}$ & $3.17 \pm 0.12^{b}$ & $1.26 \pm 0.04^{\mathrm{d}}$ \\
\hline $\mathbf{T R}_{\mathbf{1 0 5}}\left(\mathrm{mg} \mathrm{L}^{-1}\right)$ & $161.1 \pm 4.4^{\mathrm{a}}$ & $104.5 \pm 2.2^{d}$ & $99.8 \pm 1.8^{\mathrm{d}}$ & $93.8 \pm 3.2^{\mathrm{d}}$ & $118.3 \pm 2.9^{\mathrm{c}}$ & $131.9 \pm 2.9^{b}$ & $92.8 \pm 2.7^{\mathrm{d}}$ \\
\hline Coliforms (NMP 100mL-1) & $3.8 \times 10^{4} \pm 2 \times 10^{3} \mathrm{a}$ & $1.5 \times 10^{4} \pm 1 \times 10^{3} \mathrm{~b}$ & $1.2 \times 10^{4} \pm 690^{b}$ & $210 \pm 46^{c}$ & $446 \pm 117^{c}$ & $2.9 \times 10^{3} \pm 249^{c}$ & $423 \pm 79^{c}$ \\
\hline $\mathbf{N}$ & 170 & 161 & 161 & 173 & 174 & 173 & 162 \\
\hline
\end{tabular}

The means ( \pm SE) followed by the same letter (in the comparative between sites) did not differ statistically from each other by the Tukey test at $95 \%$ confidence. EC - Electrical Conductivity; DO - Dissolved Oxygen; BOD 5 - Biochemical Oxygen Demand; $\mathrm{TR}_{105}=$ Total solid residue at $105^{\circ} \mathrm{C} . \mathrm{N}=$ average number of data per sampling site. 
Table 2. Historical means (2000 to 2011) of metals in surface sediments around the Jacuí's Delta.

\begin{tabular}{|c|c|c|c|c|c|c|c|}
\hline Parameters & $\begin{array}{c}31 \\
\text { Gravataí River }\end{array}$ & $\begin{array}{c}36 \\
\text { Navegantes }\end{array}$ & $\begin{array}{c}\text { 41B } \\
\text { Lake Guaíba }\end{array}$ & $\begin{array}{c}\mathbf{5 7} \\
\text { Jacuí River }\end{array}$ & $\begin{array}{c}\mathbf{5 8} \\
\text { Caí River }\end{array}$ & $\begin{array}{c}\mathbf{5 9} \\
\text { Sinos River }\end{array}$ & $\begin{array}{c}\text { 86A } \\
\text { Ilha da Pintada }\end{array}$ \\
\hline Al $\left(\mathrm{mg} \mathrm{g}^{-1}\right)$ & $45.9 \pm 3.2^{\mathrm{abc}(1)}$ & $54.3 \pm 4.3^{\text {a }}$ & $44.5 \pm 5.5^{a b c}$ & $33.9 \pm 2.5^{b c}$ & $47.7 \pm 3.5^{\mathrm{ab}}$ & $30.4 \pm 2.9^{c}$ & $31.5 \pm 2.9^{b c}$ \\
\hline $\mathbf{F e}\left(\mathrm{mg} \mathrm{g}^{-1}\right)$ & $28.6 \pm 2.9^{b}$ & $38.4 \pm 1.9^{b}$ & $34.4 \pm 4.6^{\mathrm{b}}$ & $36.3 \pm 3.5^{b}$ & $52.5 \pm 2.9^{\mathrm{a}}$ & $30.6 \pm 2.9^{b}$ & $32.2 \pm 1.8^{b}$ \\
\hline Ca $\left(\mathrm{mg} \mathrm{g}^{-1}\right)$ & - & $3.6 \pm 0.2^{\mathrm{a}}$ & $1.9 \pm 0.3^{b}$ & - & - & - & $2.3 \pm 0.2^{b}$ \\
\hline $\mathbf{M n}\left(\mathrm{mg} \mathrm{kg}^{-1}\right)$ & $276.4 \pm 12.4^{d}$ & $484.7 \pm 36.0^{\mathrm{bc}}$ & $423.6 \pm 40.8^{\mathrm{cd}}$ & $661.7 \pm 48.6^{b}$ & $929.2 \pm 42.4^{\mathrm{a}}$ & $438.6 \pm 31.8^{\mathrm{cd}}$ & $539.3 \pm 62.7^{b c}$ \\
\hline $\mathbf{B a}\left(\mathrm{mg} \mathrm{kg}^{-1}\right)$ & $179.1 \pm 11.5^{\mathrm{ab}}$ & $196.0 \pm 11.4^{\mathrm{a}}$ & $138.7 \pm 16.9^{b c}$ & $196.9 \pm 11.2^{\mathrm{a}}$ & $229.0 \pm 9.4^{\mathrm{a}}$ & $121.9 \pm 9.1^{\mathrm{c}}$ & $187.5 \pm 14.7^{a b}$ \\
\hline $\mathbf{C u}\left(\mathrm{mg} \mathrm{kg}^{-1}\right)$ & $64.3 \pm 4.7^{\mathrm{b}}$ & $103.5 \pm 6.2^{\mathrm{a}}$ & $41.0 \pm 6.7^{\mathrm{c}}$ & $52.4 \pm 5.0^{\mathrm{bc}}$ & $65.5 \pm 4.5^{\mathrm{b}}$ & $43.2 \pm 3.7^{c}$ & $39.2 \pm 3.1^{\mathrm{c}}$ \\
\hline $\mathbf{P b}\left(\mathrm{mg} \mathrm{kg}^{-1}\right)$ & $50.0 \pm 4.2^{\mathrm{a}}$ & $62.7 \pm 4.6^{\mathrm{a}}$ & $26.1 \pm 3.7^{b}$ & $20.7 \pm 3.4^{b}$ & $29.9 \pm 3.5^{b}$ & $19.7 \pm 3.5^{b}$ & $24.8 \pm 2.9^{b}$ \\
\hline $\mathbf{C r}\left(\mathrm{mg} \mathrm{kg}^{-1}\right)$ & $33.1 \pm 3.6^{\mathrm{b}}$ & $51.8 \pm 3.6^{\mathrm{a}}$ & $22.1 \pm 2.8^{b c}$ & $21.6 \pm 1.7^{\mathrm{bc}}$ & $51.1 \pm 4.8^{\mathrm{a}}$ & $54.4 \pm 4.4^{\mathrm{a}}$ & $18.0 \pm 1.2^{\mathrm{c}}$ \\
\hline $\mathbf{N i}\left(\mathrm{mg} \mathrm{kg}^{-1}\right)$ & $22.8 \pm 2.1^{b}$ & $37.3 \pm 2.5^{\mathrm{a}}$ & $18.9 \pm 2.5^{b}$ & $22.9 \pm 2.3^{b}$ & $42.2 \pm 2.9^{\mathrm{a}}$ & $26.2 \pm 2.6^{b}$ & $20.8 \pm 2.0^{b}$ \\
\hline $\mathbf{C o}\left(\mathrm{mg} \mathrm{kg}^{-1}\right)$ & - & $28.5 \pm 1.8^{\mathrm{a}}$ & $15.3 \pm 2.0^{b}$ & $15.0^{(2)}$ & - & - & $21.6 \pm 1.6^{b}$ \\
\hline $\mathbf{H g}\left(\mathrm{mg} \mathrm{kg}^{-1}\right)$ & $0.16 \pm 0.01^{\mathrm{b}}$ & $0.43 \pm 0.04^{\mathrm{a}}$ & $0.12 \pm 0.02^{\mathrm{bc}}$ & $0.05 \pm 0.00^{\mathrm{c}}$ & $0.08 \pm 0.01^{\mathrm{bc}}$ & $0.16 \pm 0.02^{b}$ & $0.06 \pm 0.00^{\mathrm{c}}$ \\
\hline $\mathbf{A s}\left(\mathrm{mg} \mathrm{kg}^{-1}\right)$ & ND & ND & ND & ND & ND & ND & ND \\
\hline $\operatorname{Ag}\left(\mathrm{mg} \mathrm{kg}^{-1}\right)$ & ND & ND & ND & ND & ND & ND & ND \\
\hline $\mathbf{N}$ & 16 & 16 & 17 & 17 & 16 & 17 & 16 \\
\hline
\end{tabular}

${ }^{(1)}$ The means ( \pm SE) followed by the same letter (in the comparative between sites) did not differ statistically from each other by the Tukey test at $95 \%$ confidence. ${ }^{(2)}$ No repetitions. $\mathrm{ND}=$ not detected. $\mathrm{N}=$ average number of data per sampling site. 
According to the Brazilian reference values for surface waters (Table 3), Conama No. 357 - Class 2 (Conama, 2005), Points 31 (Gravataí River) and 59 (dos Sinos River) surpass the mean values for DO and Coliforms (Table 1). However, self-purification re-establishes the DO levels in the Navegantes Channel (36), but does not reduce the coliform levels below the resolution limits.

According to the Brazilian reference values for dredged sediments (Level 1) of Conama No. 454 (Conama, 2012), the mean values were above the limits proposed in sediment for $\mathrm{Zn}$ (at Points 31, 36, 41B, 58, and 59), $\mathrm{Pb}$ (31 and 36), $\mathrm{Cr}(36,58$, and 59) and $\mathrm{Hg}(36)$. The site that presented the most values above the limits (besides the highest concentrations) was 36 (Navegantes Channel), where the water flow from all those rivers accumulate . Sites 57 (Jacuí River) and 86A (Ilha da Pintada Channel) did not present any values above the proposed limits. Site 41B (Lake Guaíba) only presents the concentrations of $\mathrm{Zn}$ above the limit.

The association of the analyzed parameters is corroborated by the correlation (r) of their attributes. The increase in $\mathrm{P}$ and $\mathrm{N}$ concentrations leads to an increase in $\mathrm{BOD}_{5}(0.72$ and 0.70 , respectively; $p<0.05)$, which in turn reduces DO concentrations $(-0.62 ; p<0.05)$. This chain reaction occurs by the eutrophication of the water, consuming the oxygen available for the decomposition of the organic compounds from urban pollution (Andrade and Giroldo, 2014).

Previous studies in the Jacuí's Delta and Lake Guaíba show seasonal variations and the negative influence of pollution on river water quality and phytoplankton composition (Rodrigues et al., 2007; Andrade et al., 2012; Andrade and Giroldo, 2014). These studies point to the Gravataí River outflow (Point 31 ) as a highly degraded point relative to other points, as can be seen in the cluster analysis (Figure 2a).

Considering the historical values, the time (years) and the seasonality (months) had influence on the water parameters (Table 3) in Lake Guaíba (site 41B). Time (years) presents correlations (r) with the depth (-0.80), $\mathrm{pH}(-0.73)$, and electrical conductivity $(0.73)$; and the air temperature (seasonal variation in the months) presents correlations (r) with the depth $(-0.86)$, $\mathrm{pH}(0.83)$, dissolved oxygen (-0.85) and phosphorus (-0.80). The monthly variations (depth, $\mathrm{pH}, \mathrm{DO}$, and $\mathrm{P}$ ) can be explained by the rainy seasons, with more rainfall in the winter (Aug $140 \mathrm{~mm}$ ) and less between the summer-autumn (Apr - $86 \mathrm{~mm})$, influencing the water flow in the lake (Porto Alegre, 2017a). The reduction in the depth through the years (2000-2014) is natural, due to the deposition of sediments. However, the reduction of $\mathrm{pH}$ and increase of electrical conductivity (EC) probably occurred due to pollution.

Time (years) influenced the sediment (Table 4), reducing the concentration of some elements $(\mathrm{Ca}, \mathrm{Mn}, \mathrm{Ba}, \mathrm{V}, \mathrm{Pb}, \mathrm{Co}, \mathrm{Li}, \mathrm{Be}$, and $\mathrm{Hg})$. The reduction in values of $\mathrm{Pb}\left(\mathrm{r}-0.90 ; \mathrm{R}^{2}\right.$ $0.80)$ and $\mathrm{Hg}\left(\mathrm{r}-0.82 ; \mathrm{R}^{2} 0.67\right)$ is especially significant given the high toxicity of both metals. This decrease occurred throughout the world by the environmental pressure to control these priority metals (Bing et al., 2016).

The Rivers Caí, Gravataí, and Sinos are publicly known for their pollution, flowing through industrial areas in a metropolitan region, suffering many environmental impacts. Thus, the remediation and protection of Jacuí's Delta and Lake Guaíba are made even more complex by the liabilities upstream. 
Table 3. Historic data (means) of water parameters in the site 41B - Lake Guaíba.

\begin{tabular}{|c|c|c|c|c|c|c|c|c|c|c|c|c|c|}
\hline Parameters & air & water & depth & pH & EC & Secchi & Turbidity & DO & BOD $_{5}$ & $\mathbf{P}$ & $\mathbf{N}$ & $\mathbf{T R}_{105}$ & Coliforms \\
\hline dates & ${ }^{\circ} \mathrm{C}$ & ${ }^{\circ} \mathrm{C}$ & $\mathrm{m}$ & - & $\mu \mathrm{S} \mathrm{cm}^{-1}$ & $\mathrm{~cm}$ & NTU & $\mathrm{mg} \mathrm{L}^{-1}$ & $\mathrm{mg} \mathrm{L}^{-1}$ & $\mathrm{mg} \mathrm{L}^{-1}$ & $\mathrm{mg} \mathrm{L}^{-1}$ & $\mathrm{mg} \mathrm{L}^{-1}$ & MPN \\
\hline 2000 & 20.7 & 21.2 & 10.5 & 7.4 & 79.9 & 27.9 & 47.0 & 6.19 & 1.72 & - & 2.15 & 112.2 & 12,575 \\
\hline 2001 & 23.1 & 22.2 & 10.4 & 7.2 & 73.3 & 31.7 & 38.4 & 5.68 & 1.66 & - & 2.40 & 103.6 & 13,575 \\
\hline 2002 & 21.7 & 21.0 & 10.8 & 7.2 & 72.1 & 35.8 & 32.6 & 6.32 & 1.63 & 0.14 & 1.58 & 97.4 & 10,191 \\
\hline 2003 & 22.8 & 22.1 & 10.3 & 7.0 & 77.9 & 36.8 & 36.9 & 5.65 & 1.44 & 0.19 & 1.77 & 91.0 & 7,339 \\
\hline 2004 & 20.4 & 21.1 & 9.8 & 6.9 & 80.5 & 48.8 & 27.7 & 6.37 & 2.01 & 0.15 & 1.66 & 92.0 & 9,591 \\
\hline 2005 & 21.4 & 21.3 & 9.2 & 7.1 & 84.3 & 52.5 & 25.1 & 6.46 & 2.15 & 0.14 & 1.78 & 99.4 & 12,091 \\
\hline 2006 & 21.3 & 21.5 & 9.5 & 7.1 & 82.3 & 53.3 & 27.2 & 6.24 & 2.01 & 0.15 & 2.40 & 90.7 & 11,308 \\
\hline 2007 & 21.6 & 21.3 & 9.3 & 6.8 & 77.7 & 44.6 & 31.9 & 5.88 & 1.65 & 0.15 & 2.15 & 112.3 & 11,083 \\
\hline 2008 & 19.5 & 21.2 & 9.4 & 7.0 & 79.8 & 46.7 & 29.4 & 5.95 & 1.87 & 0.19 & 1.95 & 104.3 & 14,854 \\
\hline 2009 & 20.6 & 21.2 & 9.4 & 7.0 & 80.8 & 46.3 & 31.0 & 6.06 & 1.55 & 0.15 & 1.97 & 99.7 & 13,308 \\
\hline 2010 & 19.6 & 20.3 & 9.5 & 7.1 & 80.4 & 40.0 & 32.0 & 6.38 & 1.48 & 0.17 & 1.84 & 93.7 & 13,366 \\
\hline 2011 & 21.0 & 20.6 & 8.7 & 6.8 & 79.7 & 41.3 & 36.4 & 6.26 & 1.95 & 0.18 & 2.47 & 93.3 & 19,250 \\
\hline 2012 & 22.0 & 22.0 & 8.7 & 7.0 & 92.9 & 53.8 & 28.6 & 5.72 & 2.28 & 0.15 & 2.56 & 104.7 & 9,336 \\
\hline 2013 & 19.5 & 20.7 & 8.5 & 6.9 & 88.1 & 44.5 & 29.3 & 5.72 & 1.51 & 0.15 & 2.04 & 99.4 & 14,872 \\
\hline 2014 & 17.3 & 17.8 & 9.7 & 6.9 & 88.6 & 36.7 & 40.4 & 5.60 & 1.05 & 0.14 & 2.08 & 113.5 & 6,750 \\
\hline$r_{\text {year }}$ & -0.62 & -0.57 & -0.80 & -0.73 & 0.73 & 0.41 & -0.26 & -0.29 & -0.16 & -0.01 & 0.29 & 0.10 & 0.14 \\
\hline Jan & 27.2 & 27.1 & 9.3 & 7.2 & 75.5 & 48.2 & 25.9 & 5.79 & 1.59 & 0.14 & 1.82 & 92.3 & 9,743 \\
\hline Feb & 26.5 & 27.2 & 9.3 & 7.2 & 81.4 & 49.3 & 22.3 & 5.84 & 1.82 & 0.12 & 1.76 & 82.7 & 10,057 \\
\hline Mar & 26.2 & 25.7 & 9.3 & 7.1 & 76.2 & 50.0 & 24.4 & 5.64 & 1.63 & 0.13 & 1.54 & 96.1 & 10,621 \\
\hline Apr & 22.0 & 22.6 & 9.2 & 7.1 & 84.3 & 54.6 & 25.2 & 6.02 & 1.72 & 0.14 & 1.58 & 86.7 & 10,909 \\
\hline May & 18.0 & 18.3 & 9.7 & 6.9 & 84.1 & 51.3 & 25.1 & 6.33 & 1.48 & 0.15 & 1.85 & 100.1 & 12,260 \\
\hline Jun & 17.0 & 16.0 & 9.9 & 7.0 & 85.3 & 43.5 & 30.8 & 6.69 & 1.70 & 0.18 & 2.10 & 101.6 & 16,115 \\
\hline Jul & 13.3 & 14.8 & 9.8 & 6.9 & 86.9 & 37.5 & 47.3 & 6.86 & 2.35 & 0.20 & 2.48 & 110.4 & 13,564 \\
\hline Aug & 16.7 & 15.8 & 9.7 & 6.9 & 81.1 & 37.9 & 35.0 & 6.56 & 1.70 & 0.17 & 2.30 & 108.4 & 11,179 \\
\hline Sep & 17.1 & 17.7 & 9.9 & 7.0 & 78.3 & 32.5 & 41.0 & 6.23 & 1.91 & 0.17 & 1.96 & 105.4 & 13,254 \\
\hline Oct & 20.6 & 20.7 & 9.8 & 6.9 & 76.6 & 34.7 & 45.0 & 5.57 & 1.69 & 0.18 & 2.19 & 111.2 & 13,847 \\
\hline Nov & 23.9 & 23.7 & 9.4 & 7.1 & 80.6 & 33.9 & 41.2 & 5.53 & 1.82 & 0.17 & 2.30 & 101.9 & 11,577 \\
\hline Dez & 23.5 & 24.9 & 9.5 & 7.1 & 79.6 & 43.2 & 26.4 & 5.71 & 1.90 & 0.16 & 1.82 & 99.9 & 14,700 \\
\hline $\mathrm{r}_{\text {air }}{ }^{\circ} \mathrm{C}$ & - & 0.99 & -0.86 & 0.83 & -0.62 & 0.45 & -0.60 & -0.85 & -0.43 & -0.80 & -0.65 & -0.71 & -0.59 \\
\hline Conama No. 357 & - & - & - & $6-9$ & - & - & 100 & 5 & 5 & 0.05 & 3.7 & - & 1,000 \\
\hline
\end{tabular}


Table 4. Historic data (means) of metals in surface sediments in the site 41B - Lake Guaíba.

\begin{tabular}{|c|c|c|c|c|c|c|c|c|c|c|c|c|c|c|c|c|}
\hline Year & Al & $\mathrm{Fe}$ & $\mathbf{C a}$ & Mn & Ba & V & $\mathbf{Z n}$ & $\mathrm{Cu}$ & $\mathbf{P b}$ & $\mathrm{Cr}$ & $\mathbf{N i}$ & Co & $\mathbf{L i}$ & $\mathbf{B e}$ & Cd & $\mathrm{Hg}$ \\
\hline & \multicolumn{3}{|c|}{$\mathrm{mg} \mathrm{g}^{-1}$} & \multicolumn{13}{|c|}{$\mathrm{mg} \mathrm{kg}^{-1}$} \\
\hline 2000 & 45.8 & 57.0 & 2.7 & 680 & 275 & 130 & 218 & 81.0 & 49.0 & 38.5 & 23.0 & 23.0 & 18.0 & 4.0 & 0.30 & 0.25 \\
\hline 2001 & 72.4 & 47.7 & 2.8 & 696 & 220 & 185 & 219 & - & 50.0 & 40.5 & 36.5 & 27.0 & 17.5 & 3.5 & 0.25 & 0.24 \\
\hline 2002 & 69.5 & 47.1 & 2.8 & 695 & - & 130 & 209 & - & 30.0 & 39.0 & 42.0 & 33.0 & 13.0 & 4.0 & 0.10 & 0.21 \\
\hline 2003 & - & - & - & - & - & - & - & - & - & - & - & - & - & - & - & - \\
\hline 2004 & 27.3 & 25.5 & 1.7 & 425 & 140 & 75 & 93.0 & - & 25.0 & 11.0 & 16.5 & 13.5 & 6.00 & 1.5 & 0.30 & 0.08 \\
\hline 2005 & 13.6 & 15.3 & 1.3 & 281 & 85 & 35 & 83.0 & 28.0 & 30.0 & 9.5 & 11.0 & 11.5 & 2.00 & 1.0 & 0.10 & 0.08 \\
\hline 2006 & 13.6 & 18.5 & 1.2 & 317 & 80 & 30 & 70.5 & 28.5 & 25.0 & 13.0 & 12.0 & 10.0 & 2.50 & 1.0 & 0.20 & 0.07 \\
\hline 2007 & 33.6 & 28.3 & 1.0 & 505 & 175 & 70 & 125 & 49.0 & 10.0 & 22.0 & 19.5 & 14.0 & 9.50 & 2.0 & 0.10 & 0.06 \\
\hline 2008 & 40.7 & 34.4 & - & 335 & 140 & 40 & 212 & 68.0 & 13.0 & 33.5 & 27.5 & 18.5 & 8.00 & 1.0 & 0.30 & 0.14 \\
\hline 2009 & 84.9 & - & - & 313 & 93 & 24 & 65.5 & 27.1 & 11.4 & 14.5 & 9.19 & 5.50 & 4.50 & - & 0.16 & 0.08 \\
\hline 2010 & 48.5 & - & - & 214 & 75 & 20 & 58.2 & 28.0 & 10.3 & 12.0 & 8.21 & 5.14 & 3.78 & 0.6 & 0.17 & 0.04 \\
\hline 2011 & 60.1 & - & - & 249 & 70 & 20 & 78.0 & 23.0 & 16.0 & 14.0 & 9.00 & 6.00 & 4.00 & 1.0 & 0.10 & 0.07 \\
\hline $\mathrm{R}^{2}$ & 0.00 & 0.54 & 0.92 & 0.76 & 0.66 & 0.76 & 0.47 & 0.44 & 0.80 & 0.42 & 0.47 & 0.67 & 0.59 & 0.72 & 0.15 & 0.67 \\
\hline $\mathrm{r}$ & 0.02 & -0.74 & -0.96 & -0.87 & -0.81 & -0.87 & -0.69 & -0.66 & -0.90 & -0.65 & -0.69 & -0.82 & -0.77 & -0.85 & -0.39 & -0.82 \\
\hline mean & 46.4 & 34.2 & 1.93 & 428 & 135 & 69.0 & 130 & 41.6 & 24.5 & 22.5 & 19.5 & 15.2 & 8.07 & 1.96 & 0.19 & 0.12 \\
\hline$\pm \mathrm{se}$ & 7.1 & 5.3 & 0.31 & 56 & 22 & 16.9 & 21 & 7.8 & 4.4 & 3.8 & 3.5 & 2.8 & 1.74 & 0.43 & 0.03 & 0.02 \\
\hline
\end{tabular}

No detection for As and Ag. No differences between months. $\mathrm{R}^{2}$ - coefficient of determination; r - correlation coefficient; \pm se - standard error. 


\section{CONCLUSIONS}

The historical data of water and sediment around the Jacuí's Delta shows the influence of the tributaries with low quality in the downstream points. The pollution of the Rivers Caí, Sinos, and Gravataí negatively affect the environmental quality of Navegantes Channel and Lake Guaíba (catchment points to water supply). The water in those sites present reductions in dissolved oxygen and high values of coliforms, and the sediment shows high concentrations of metal $\mathrm{Zn}, \mathrm{Pb}, \mathrm{Cr}$, and $\mathrm{Hg}$. Despite a reduction in past years in $\mathrm{Pb}$ and $\mathrm{Hg}$ values in the sediment, pollution from the tributary rivers persists.

\section{ACKNOWLEDGEMENTS}

We thank the Municipal Department of Water and Sewage (Dmae) of Porto Alegre for the data and the National Council for Scientific and Technological Development (CNPq) for the doctoral scholarship to the first author.

\section{REFERENCES}

ADAMIEC, E.; JAROSZ-KRZEMINSKA, E.; WIESZALA, R. Heavy metals from nonexhaust vehicle emissions in urban and motorway road dusts. Environmental Monitoring and Assessment, v. 188, n. 6, p. 369-379, 2016. http://dx.doi.org/10.1007/s10661-016-5377-1

ANDRADE NETO, J. S.; RIGON, L. T.; TOLDO JR., E. E.; SCHETTINI, C. A. F. Descarga sólida em suspensão do sistema fluvial do Guaíba, RS, e sua variabilidade temporal. Pesquisas em Geociências, v. 39, n. 2, p. 161-171, 2012.

ANDRADE, L. C.; TIECHER, T.; OLIVEIRA, J. S.; ANDREAZZA, R.; INDA, A. V.; CAMARGO, F. A. O. Sediment pollution in margins of the Lake Guaíba, Southern Brazil. Environmental Monitoring and Assessment, n. 190, n. 3, p. 13, 2018. http://dx.doi.org/10.1007/s10661-017-6365-9

ANDRADE, R. R.; COLARES, E. R. C.; KRIGGER, S. S.; MAIZONAVE, C. R. M.; MORANDI, I. C. Lago Guaíba (RS): índice de qualidade da água - IQA, 2000 a 2009. ECOS Técnica, n. 4, p. 5-14, 2012.

ANDRADE, R. R.; GIROLDO, D. Limnological characterisation and phytoplankton seasonal variation in a subtropical shallow lake (Lake Guaíba, Brazil): a long-term study. Acta Limnologica Brasiliensia, v. 26, n. 4, p. 442-456, 2014. http://dx.doi.org/10.1590/S2179-975X2014000400011

BING, H.; WU, Y.; ZHOU, J.; LI, R.; WANG, J. Historical trends of anthropogenic metals in Eastern Tibetan Plateau as reconstructed from alpine lake sediments over the last century. $\begin{array}{lllll}\text { Chemosphere, } & \text { v. } & 148, & \text { p. } & 211-219,\end{array}$ http://dx.doi.org/10.1016/j.chemosphere.2016.01.042

CAVAlCANTI, P. P.; RODRIGUES, L. C. A.; BEIJO, L. A.; BARBOSA, S.; XAVIER, T. T.; MAGALHÃES, F. Contamination from an affluent of Furnas reservoir by trace metals. Brazilian Journal of Biology, n. 74, p. 877-885, 2014. http://dx.doi.org/10.1590/1519-6984.07013 
CONSELHO NACIONAL DO MEIO AMBIENTE - CONAMA (Brasil). Resolução No. 357, de 17 de março de 2005. Dispõe sobre a classificação dos corpos de água e diretrizes ambientais para o seu enquadramento, bem como estabelece as condições e padrões de lançamento de efluentes, e dá outras providências. Diário Oficial [da] União, Brasília, DF, 18 mar 2005.

CONSELHO NACIONAL DO MEIO AMBIENTE - CONAMA (Brasil). Resolução No. 454, de 01 de novembro de 2012. Estabelece as diretrizes gerais e os procedimentos referenciais para o gerenciamento do material a ser dragado em águas sob jurisdição nacional. Diário Oficial [da] União, Brasília, DF, 08 set 2012.

FREITAS, A. F. R. O destino dos esgotos de Porto Alegre em face da poluição do Guaíba. Porto Alegre: Ed. da Universidade do Rio Grande do Sul, 1962. 39 p.

MENEGAT, R.; PORTO, M. L.; CARRARO, C. C.; FERNANDES, L. A. A. (Coord.). Atlas ambiental de Porto Alegre. 3. ed. Porto Alegre: Editora da UFRGS, 2006. 228 p.

PORTO ALEGRE. Centro Integrado de Comando - CEIC. Dados históricos das estações meteorológicas.

Available

in: http://www2.portoalegre.rs.gov.br/ceic/default.php?p_secao=28. Access in May 2017.

PORTO ALEGRE. Departamento Municipal de Água e Esgotos - Dmae. Lago Guaíba. Available in: http://www2.portoalegre.rs.gov.br/dmae/default.php?p_secao=197. Access in: Feb. 2017.

RODRIGUES, S. C.; TORGAN, L.; SCHWARZBOLD, A. Composição e variação sazonal da riqueza do fitoplâncton na foz de rios do delta do Jacuí, RS, Brasil. Acta Botanica Brasilica, v. 21, n. 3, p. 707-721, 2007. http://dx.doi.org/10.1590/S010233062007000300017

ROESSLER, H. L. O Rio Grande do Sul e a ecologia. 2. ed. Porto Alegre: Governo do Estado do Rio Grande do Sul/SEMA/FEPAM, 2005. 219 p.

SHARLEY, D. J.; SHARP, S. M.; BOURGUES, S.; PETTIGROVE, V. J. Detecting long-term temporal trends in sediment-bound trace metals from urbanized catchments. $\begin{array}{llllll}\text { Environmental Pollution, } & \text { v. 219, p. }\end{array}$ http://dx.doi.org/10.1016/j.envpol.2016.06.072

SMOL, J. P. Pollution of lakes and rivers: a paleoenvironmental perspective. $2^{\text {nd }}$ ed. Malden: Blackwell Publishing, 2008.

UNITED STATES. Environmental Protection Agency - USEPA. Method 3051A: Microwave assisted acid digestion of sediments, sludges, soils, and oils. Washington, 2007.

ZHANG, Z.; WANG, J. J.; ALI, A.; DELAUNE, R. D. Heavy metals and metalloid contamination in Louisiana Lake Pontchartrain Estuary along I-10 Bridge. Transportation Research Part D: Transport and Environment, v. 44, p. 66-77, 2016. http://dx.doi.org/10.1016/j.trd.2016.02.014 